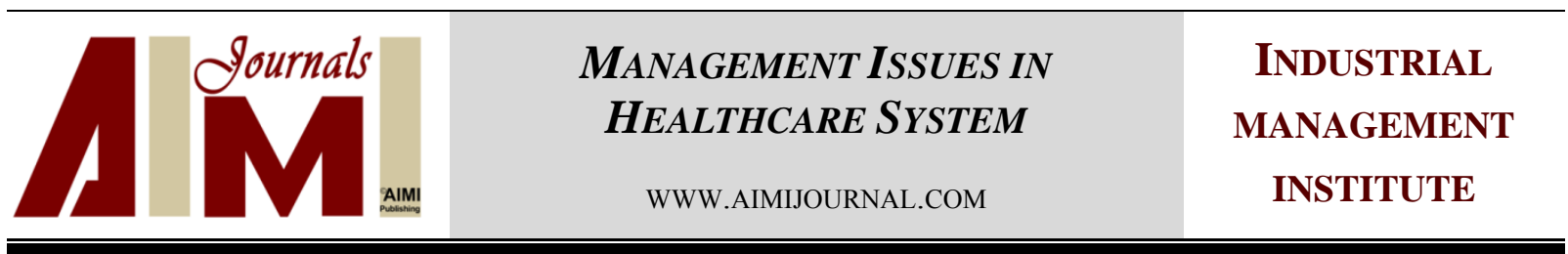

\title{
Valuation of human resources in organization
}

\author{
Jalal Delavaripour ${ }^{1}$, Morvarid Alishiri ${ }^{2 *}$ \\ ${ }^{1}$ MA of Business Management, Department of Management, Shahid Chamran University of Ahvaz, Ahvaz, \\ Iran \\ ${ }^{2}$ MA of Financial Management, Faculty of Management, Alameh Tabatabai University, Tehran, Iran
}

\begin{abstract}
Keywords: Intellectual Capital, Human Capital, Human Capital Accounting

Correspondence: delavarijalal@yahoo.com morvarid.alishiry@yahoo.c om

This study was conducted to develop an analysis framework to link the human capital costs to the results of long-term interests or profits for providing a model for representing human capital on the balance sheet. This framework introduced various types of accounting methods for human capital performance-related payments. This paper represented a set of expenses which are controlled by organizations and some of economic benefits of these costs that occur in different time periods for investment. In addition, there were also some costs that did not provide long-term benefits or were less productive that should be taken into account. Finally, this study tried to represent the amortization of the human capital as an asset on the balance sheet by applying mathematical models.
\end{abstract}

(C)AIMI Journals

\section{Introduction}

Nowadays, the organizations are witnessed a new economic era. During this era, the organizations not only produce new goods and services but also they create added value for their survival. In this period, there is an emphasis on one particular form of resources (intellectual capital) which is different from other types of resources such as physical and financial capital (Rylander, Jacobson, \& Roos, 2000; Zeghal \& Maaloul, 2010). Intellectual capital (human and structural) is considered as capital employed (physical and financial) and strategic resource from resource-based theory view.

This theory states that companies gain competitive advantage and better financial performance through acquisition, maintenance, and efficient use of strategic resources 
(Barney, 1991; Peteraf, 1993). Intellectual capital based theory is also consistent with this point of view. These two approaches have similar goals. Resource- based theory view has a strong focus on the company's performance as the key outcome variable through the effective use of company resources while intellectual capital based theory view considers intellectual capital as an intangible asset and strategic resource that gives opportunity to the organization to create added value (Andreou, Green, \& Stankosky, 2007; Reed, Lubatkin, \& Srinivasan, 2006). Pulic (2004) believed that the intellectual capital cannot operate independently without physical and financial capital's support. On the other hand, measuring intellectual capital is so difficult task because it is inherently intangible and non-physical in nature (Zeghal \& Maaloul, 2010). Assessing the value added by an organization during a particular period is based on the theory of stakeholder view. The stakeholder theory suggests that everyone who affects and be affected by what a firm does have an interest in the organization.

\section{Definition of Intellectual Capital}

The concept of intellectual property was first introduced in 1969 by John Kenneth Galbraith. In his view, intellectual capital as a mental activity means beyond the concept of thinking like pure speculation and covers a degree of mental treatment (Bontis, Dragonetti, Jacobsen, \& Roos, 1999). In this sense, intellectual capital is not just a static intangible asset but also is an ideal process. Intellectual capital is a movement of human capital (knowledge and skills) toward intellectual property (the use the knowledge and skills) (Chang, 2007). Intellectual capital or intangible asset is the main source of modern organizations. Although, many of organizations cannot clearly define the various components of intangible assets (Samudhram, Sivalingam, \& Shanmugam, 2010). The related literature shows that there are various definitions for the intellectual capital and intangible assets. Non-accounting researchers define intellectual capital as the cumulative difference between organization's market value and book value of the company (Edvinsson \& Malone, 1997; Sveiby, 1997) while accounting researchers defined goodwill as the differences between the organization's market value and the book value of business recognized assets. In accounting area, goodwill is an intangible asset that arises when a buyer acquires an existing business (Beaver, 1998; Ohlson, 1995). In literature, there is no universal definition for intellectual capital, but in vast majority of them, intellectual capital (intangible asset) is considered as a non-monetary asset without physical existence which is valuable or can provide future benefits (Choong, 2008). Hall (1992) believed that intangible assets are value drivers which convert the productive resources into the value added assets. He divided the intangible assets into two categories including intellectual property and knowledge assets. Intangible assets strengthen the capability coefficients and actually increase sustainable competitive advantage (Choong, 2008).

\section{Classifications of Intellectual Capital}

In the late 1990s, a number of authors such as Brooking (1996), Edvinsson and Malone (1997), and Sveiby (1997) proposed a framework which helps us to conceptualize and operationalize the concept of intellectual capital. In the realm of intellectual capital, all studies emphasize that there is not one dimensional structure for intellectual capital and this type of capital is located within different levels of organization including individual, internal, 
and external of the organization. This means that intellectual capital is not limited to individual knowledge but rather it is the stored knowledge in an organization's databases, processes, systems, and relationships (Chang, 2007). Edvinsson and Malone (1997) defined intellectual capital as knowledge ownership, stated that the intellectual capital has two main components including human capital such as knowledge, skills, and experience of staff and structural capital consists of embodiment, empowerment, and supporting infrastructure of human capital (Figure 1). Researchers divide experience, organizational technology, customer relationships, and professional skills that make a competitive edge in the market and insight related to the future income capabilities. They divide structural capital into organizational capital (systems, tools, and operational duty that accelerates the flow of knowledge within the organization) and innovation and process capital (the relationship between the organization and its customers) due to the variety of components. There are five kinds of capital including human capital, structural capital, customer capital, organizational capital, and innovation capital. Human capital refers to the knowledge, skills, and experiences of individuals within an organization. Structural capital pointed to the visualization, strengthening, and supporting infrastructure of the human capital. Customer capital refers to the loyalty and strength of customers' relationships either within or outside of the organization. Organizational capital includes philosophy and organizational systems which are used for leveraging the organizational capabilities. Innovation capital consists of intellectual property which protects the commercial right such as copyright, trademarks, and intangible asset. Process capital includes techniques, guidelines, and programs that do the delivery of goods and services and reinforce them (Chang, 2007). Figure 1 depicts Skandia navigator model and its dimensions.

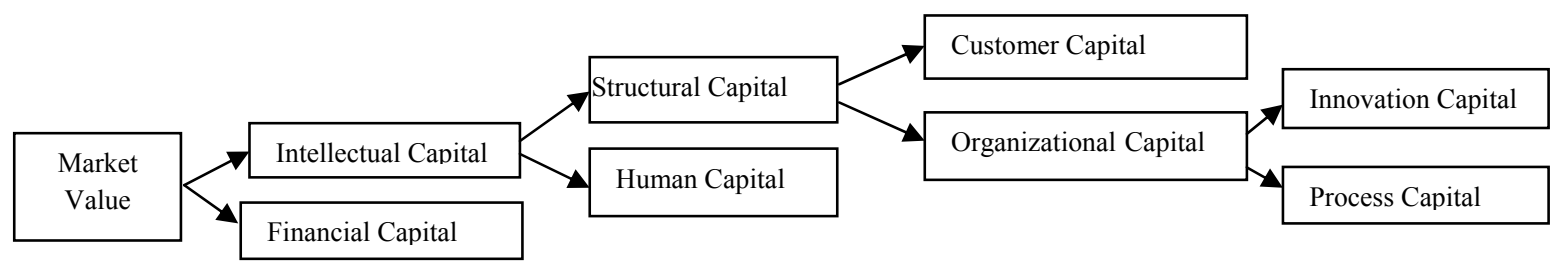

Figure 1. Skandia's navigator model (1997) and its dimensions

Edvinsson and Malone (1997) greatly helped to improve the evaluation of intellectual capital. G. Ross and J. Ross (1997) thought about a thinking method which integrates intellectual capital measures to form a single measure or holistic value perspective. Alike to Edvinsson and Malone's (1997) classification, Ross, Ross, Edvinsson, and Dragonetti (1997) divided intellectual capital into three groups consist of human capital, structural capital, and relational capital and then put these three categories into the same hierarchical level. Figure 2 shows G. Roos and J. Roos (1997) hierarchical structure of intellectual capital. 


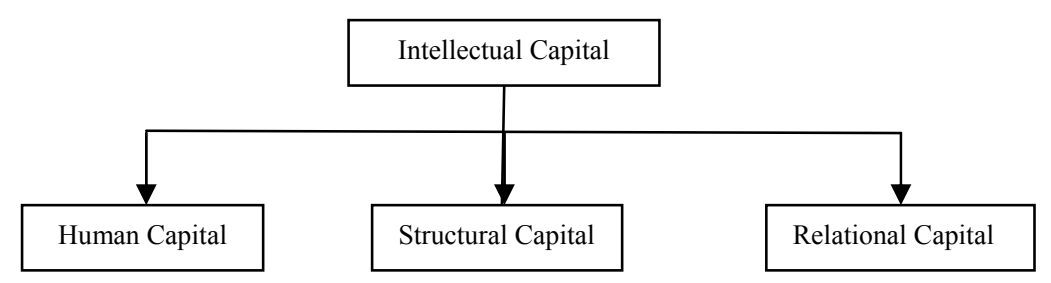

Figure 2. Hierarchical structure of intellectual capital

\section{Human Capital}

The key characteristics of employees are considered as capitals for organizations which cannot be written on paper. These capitals are resources such as competence, attitude, skill, implicit knowledge, and personal networks (Roos, Pike, \& Fernström, 2005). Human capital refers to the knowledge, skills, abilities, and individual experiences of employees in an organization (Brooking, 1996; Edvinsson \& Malone, 1997; G. Roos \& J. Roos, 1997). The concept of human capital is an important term and framework within intellectual capital domain. Human capital is defined in the individual level as the combination of individual capabilities in organizations to create a commercial value and solve business problems. The organizational learning literature suggests that the knowledge does not only guarantee the organizational learning but also the staff do it. As much as people are learning, they are creating knowledge and potentially providing a database for learning and storing knowledge in the organizational level. This highlights the fact that human capital is related to the people within the organizations. The organizations which live long normally have far more experience than the others and therefore, they have high-educated employees who have strong relationships with other organizations.

Schultz (1981), an American economist, stated that the main factors of improving the poor people's welfare are not space, energy, and cropland, but also they consist of quality improvements of the population and advances in knowledge. These advances can be strengthened by investing in human capital. Therefore, human capital refers to the accumulated value which is raised from investing in education, training, staff competency, and future. Therefore, the human capital is considered as an innovation resource and strategic modernization that depends on how effectively the organizations use it. From economic perspective, this concept emphasizes on the value that implicit knowledge can create under the ownership of organizations' individuals (Edvinsson \& Malone, 1997). Undoubtedly, we cannot put the concept of human capital directly under the ownership of an organization. The human capital can be withdrawn from an organization or imitated by competitors when its employees leave the organization. Therefore, the organizations should not only pay attention to the investment in human capabilities but also replace human activities in organizational processes as structural capitals (Chang, 2007).

\section{Structural Capital}

The most comprehensive definition of structural capital was proposed by Edvinsson (1998) who stated that all the things that remain within the organization are considered as structural capital that you cannot find it in the balance sheets when the employees have left the organization. This type of capital includes resources such as brands or trademarks, 
intellectual property, processes, systems, organizational structure, information whether on paper or in databases, and personal networks. Structural capital also includes all the relationships that an organization has with its own customers, consumers, brokers, agents, suppliers, partners, owners, and lenders (Roos et al., 2005).

\section{Physical and Financial Capitals}

Physical and financial capitals refer to the used assets that help the organizations to generate revenues and profits. According to the resource-based theory, the resources of an organization are the most important drivers of competitiveness and organizational performance. These resources consist of both tangible and intangible assets. The used capital is the accurate reflection of tangible assets and the physical capital equals the total assets minus intangible assets and financial-assets (Chen, Cheng, \& Hwang, 2005).

\section{Difference between Intellectual Capital and Physical/Financial Capitals}

Intellectual capital resources behave differently from monetary and physical resources and therefore, should be managed differently (Roos et al., 2005). There are four differences between intellectual capital and physical and financial capitals. The physical and financial resources obey the law of diminishing marginal returns. Organizational and relational resources obey the law of the network economy. This means that the final outcome of future investment of these resources will increase to achieve the milestone. Then, the final investment point leads to lower final outcome. Human resources have a desire to obey the final outcome law. This explained that as we gain more detailed knowledge about some things, we realize better that how little we know versus what is to be learned. The second difference states that physical and financial resources are under the ownership control of organization that was presented on the balanced sheet while relational resources are not. In fact, they are the only resources of intellectual capital that are under the ownership control of organization. Many of these resources are complementary for relational resources or human resources. They are considered as important databases for competitive advantage in most of organizations. Human resources are controlled by the individuals that is why employing the staff do not show the accessibility of others to their merits. Moreover, the physical and monetary resources are considered as competitors. This means that they cannot be applied simultaneously for different purposes. In contrast, intellectual capital resources have noncompetitive nature and therefore, they could be used simultaneously for different purposes. Finally, physical and financial resources have the full potential to hinder the adaptation and the legal use of these resources.

On the contrary, intellectual capital resources have partial prevention capability. This means that legally it can be very difficult to prevent others from acquiring and using their economic interests (Roos et al., 2005).

\section{Methods of Intellectual Capital}

Today, although many organizations pursue knowledge management process, but most of them either do not have a process to measure organizational knowledge and intellectual capital assets or have very superficial and limited applied indexes because of complexity of 
index creation and evaluation due to intangible nature of intellectual capital. Although performance driven models are used for evaluating the intellectual capital, but they assign much more value to intellectual capital. This issue leads to the fact that many researchers offer different views in this field. Qualitative and quantitative methods are used to measure the intellectual capital.

\section{Qualitative Methods}

These models are designed for the measurement of non-financial assets. The objective of qualitative methods is identifying what is important to the organizations and also helping the organizations to achieve their predetermined goals.

\section{Invisible Balance Sheet}

Indivisible balance sheet was introduced in Sweden as one of the leading practices in the area of intangible assets by Sveiby (1997). Sveiby reacted against the inability of traditional accounting systems to provide adequate information for rating the technical knowledge and develop a framework for reporting intangible assets which was called invisible balance sheet. The aim of publishing his book under the same title was showing a practical approach for reporting human resources which are the first generation of technical knowledge income.

\section{Intangible Asset Monitor}

Intangible asset monitor was developed by Sveiby (1997) and defined three types of intangible assets which resulted from the difference between market and book value of the company. These three components of intangible asset monitor includes the external structure, namely trademark and customer and supplier relations, the internal structure consists of management, law, guidelines, procedures, and software, and personal competence contain education, experience, and agility.

Sveiby (1997) suggested that these three categories create value for the company through one of the four directions such as growth, modernization, sustainability, and efficiency. This model is based on the premise that human being is the only major factor in business and other aspects of both internal and external are hidden in human activities.

\section{Balanced Scorecard}

Kaplan and Norton (1992) developed the method of balanced scorecard to help the businesses turn the idea into the action, achieve the long-term goals, and receive feedback about the strategy. This model originates from the company's vision and strategy and should reflect the main focus of the business. Balanced scorecard consists of four parts including explanation and interpretation of vision and strategy, communicating and sharing the strategic objectives, assessment, planning, setting the goals, setting the strategic innovations, and strengthening the strategic feedback and learning. Totally, criteria such as customer, financial, internal processes, and growth learning are applied to change the high level strategy into the actual criteria. Furthermore, the relationship between each of these factors should be taken into account. The balanced scorecard changes the focus of its attention from pure financial indexes towards three intangible success criteria compared to the traditional accounting 
criteria. These criteria are roughly the same as three components of intellectual capital means including knowledge and experience of people, structural capital consists of hidden knowledge which lies in the systems and processes, and customer capital, namely customer relationships) (Bose, 2004).

\section{Quantitative Models}

Quantitative models assigned the numerical values to the intangible assets. To support these research efforts, three approaches have been adopted in reality for evaluating intangible assets such as cost, market, and income.

\section{Cost-Based Method}

Cost-based method which is used by accountants usually reports the historical cost of developed intangible assets. Book value which is paid for a particular asset is equal to the cost of the asset minus accumulated depreciation. Book value is no longer an appropriate evaluation technique for dynamic assets such as shareholders' salary and intangible assets. Therefore, the cost-based methods have a low importance for measuring the intangible assets.

\section{Market-Based Method}

Market-based method attempts to evaluate the intellectual capital through identifying comparable assets and evaluating the value of their payment worth them to evaluate the intellectual capital.

\section{Method of Measuring Intangible Assets}

Financial method of intangible assets measuring was introduced by Rodov and Leliaert (2002). The value of intangible assets is derived through subtracting the total value of company's financial and physical assets and deducing it from the total value. This model is based on the overlapping 3-leaf model of Philippe Leliaert which is used for assessing the monetary value of intellectual capital. Leliaert's model showed that the intellectual capital is the link between human capital, customer, and the structure.

\section{Market Value vs. Book Value}

Market to book value ratio (M/ B) is used by investors to assess the companies' past performances and future expectations. Market-to-book-ratio was presented by Stewart (1997) to evaluate the intellectual capital. This value is calculated by dividing the market price per share by book value per share while Stewart stated that it is obtained through subtracting the company's market value from shareholders' book value of equity. He stated that the difference between these two values is equal to the value of company's intangible assets (Levy, 2009).

\section{Tobin's Q}

Tobin (1969) presented Tobin's Q method in an attempt to neutralize the efforts of the accountants in the use of different depreciation policies. Tobin defined Q as the market value of assets divided by the replacement value. In the long run, the amount of $Q$ tends towards 1 
from theoretical perspective. Empirical evidence shows that this ratio can change significantly from the number 1 , for example in the software companies with a high degree of intellectual capital, this ratio is about seven or higher while in companies with a lot of physical capital it is about one. The ratio of Tobin's $Q$ in principle is very similar to the ratio of book value to market to book value ratio. The difference between these two ratios comes back to the fact that Tobin's Q takes the replacement cost of physical assets instead of its book value. If one organization's ratio of Tobin's $Q$ is greater than 1 or greater than other companies' Q, that company will have a higher intellectual capital (Levy, 2009). Some researchers believe that the ratio of Tobin's Q is better than market to book value ratio because this ratio neutralizes the relative impact of different depreciation policies.

\section{Income-Based Model and Economic Value Added (EVA)}

Income-based models state that the percent of intangible assets is determined with respect to their future potential earnings. In 1999s, economic value added was presented as one other value-based performance measure. This method is one of relatively new methods of performance evaluation which was presented by Stewart and New York's consulting firm (1997). This method has focused on shareholders' wealth maximization. This method calculates the economic net worth of the company and helps the managers to create value for shareholder. Economic value added equal to the after-tax cash flow results from the business minus the spent cost of capital used in cash flow; therefore, it represents the real profit. Economic value added is considered as the difference between the net sale, total operating expenses, taxes, and capital expenditures. Capital expenditure is calculated by multiplying the weighted average cost of capital in total capital. In practice, when the economic value added increases, the weighted average cost of capital will be less than the return on net assets.

\section{Human Capital Accounting}

Bonits et al. (1999) stated that human capital which is made of the combined intelligence, skills, and expertise gives the organizations distinctive characters. The advent of human capital accounting dates back to several decades ago. Development and expansion of this term classified in five stages including creating and building the basic concepts of human resource accounting in the early to mid of 1960s, emerging of academic research and development of measurement models by the late 1960, growing the interest and attention to accounting for human capital in the early to mid 1970, paying close attention to degradation of human resource accounting by the late 1970, and renewing interest in human resource accounting since 1980. This current renewed interest in the intangible assets concept dates back to the recognizing and building the sustainable wealth capacity which is mainly derived from the intangible assets (Beaver, 1998).

\section{Models and Functions}

An acceptable model for human resource accounting can both improve internal and external reporting requirements. Moreover, a good idea of the costs and benefits of various human resource decisions can lead to better and relevant management decisions including hiring, suspension, temporary layoff, and drawdown. External reporting shows the human capital 
accounts on its annual balance sheets which are currently absent in the financial reports and improves the value relevance of financial statements. It also helps to reduce the distance between book value and market value. Brumment, Flamholtz, and Pyle (1968 a, b) pointed out to three functions of human resource accounting including presenting the numerical data in terms of cost and value of each individual within an organization, creating and providing a framework to help decision-makers, and promoting a human resource perspective among decision-makers. There are several models of valuing employees which includes monetary and non-monetary models. Non-monetary models create performance indictors to increase or decrease employees' value over time by using organizational and behavioral variables, but such kinds of models do not provide the useable monetary value on the balance sheet (Kaplan $\&$ Norton, 1992). These models which assess the monetary aspect of human capital include approaches that transform the past costs into the capital, reduce the salaries, and exploit or use the transportation costs (Levy, 2009).

\section{Value Communication of Human Capital}

The current global accounting standards do not allow us to record the human capital as an asset on the balance sheet even as a linear figure in intangible assets within the global financial reporting system. The scientific literature of the 1970's and 1980's contains several accounts of studies dealing with the influence of human resource accounting on decisionmaking. However, they expressed that such kind of information makes difference in users' decision making processes. Elias (1972) stated that human resources information has a significant impact on users' stock investment decision making processes. Schwan (1976) indicated that having information about human capital lead to more accurate forecasts of the future net income when the comparisons are only based on the conventional indicators. Oliver and Flamholtz (1978) presented some evidence that the values of human resource have a significant effect on accepted auditors' decisions and monetary or non-monetary values of human resources.

\section{Human Capital as an Asset}

One thing is known as an asset on the balance sheet when the company considers the future economic benefits as a result of past payments; therefore, the common interests will transfer to the company and these profits can be measured reliably. To recognize the human capital as an asset, we should pay attention to the related topics including the fact that employees are free to leave their company whenever they want (for example, expenses such as training for improving the employees' efficiency may not gain any interest for the company if an employee wants to be trained) and difficulty in measuring the value of benefits (such as gradual improvement at work due to training). Such kinds of issues are considered as sliding barriers in recognition of human capital on the balance sheet (Reed et al., 2006). As a matter of fact, all the employees never leave the organization and therefore, they pursue their training, especially when the training specialized for an organization and it does not apply outside that organization. It is far better for employees to remain as valuable trained resources trained in their existing organization and enjoy their obtained benefits rather than going anywhere else where their training may be less usable. To measure the future benefits with 
sufficient reliability, Likert approach is used as a basis from generally accepted accounting principles perspective. It can be assumed unlikely that the companies invest on their own potential business benefits on all their payments including the costs of acquisition, training, and maintenance of human resource. The benefits which are derived from the human resources expenses at least will be equal to or more than the monetary value of these costs (Roos et al., 2005). From the conservatism perspective, one can understand that the interests' value of the company's human capital is at least equal to the sum of related costs of human capital which is spent for them and all these costs are spread in tax statements. Although some human resource- related costs may not provide the economic benefits for the company over a period of time, some of these costs can surely provide benefits over the coming period. A full human resource-related cost analysis helps the companies to recognize the costs that create future benefits over the coming period and can be converted to investments. It furthermore helps to identify the costs that create periodical benefits for the companies. Figure 3 presents an extensive framework for surveying the various human resource-related costs. This framework classifies these costs into four categories based on the benefits that they provide (Samudhram et al., 2010). This framework states the priority in using the costs and the level that these costs should be invested or should be spent.

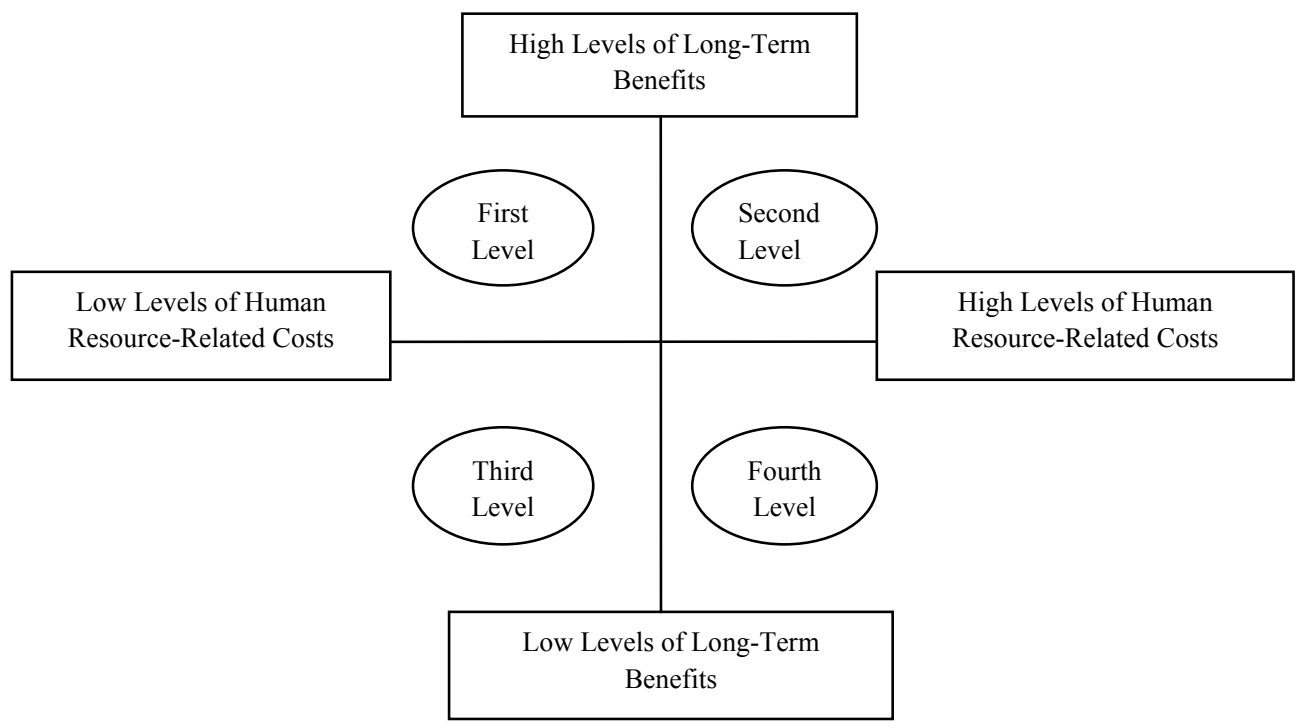

Figure 3. The extensive framework for surveying the various human resource-related costs (Samudhram et al., 2010)

\section{Analysis Framework}

Analysis framework is a tool for understanding the variety of cost-benefit relationships to develop appropriate accounting treatments and report external financial purposes for types of human resource-related costs. Furthermore, this kind of analysis has also been used as a tool to support decision making processes, manage the strategic performance, and identify the needs of management accountants. The theoretical foundation of this framework states that the relationship between human resource costs and benefits treat differently. In some cases, low investment in developing human resources may lead to long-term benefits at high levels, while investment at the same levels may lead to limited interest in other situations. In 
contrast, high levels of human resource-related costs may create a high-level or low-level of long-term benefits and analysis of framework that provides a realistic view of the situation. This framework identifies and presents four levels for human resource-related benefits (Samudhram et al., 2010). Table 1 presents different payment levels and their features in details.

Table 1

Different Payment Levels and their Features

\begin{tabular}{|c|c|c|}
\hline Payments & Definition & Features \\
\hline Level One & $\begin{array}{l}\text { Level one refers to the costs } \\
\text { which companies incur at the } \\
\text { higher levels to obtain long-term } \\
\text { benefits due to the restrictions of } \\
\text { companies' human capital. }\end{array}$ & $\begin{array}{l}\text {-Help the employees to meet and enhance their education and learning at their own } \\
\text { expense } \\
\text {-Enhance the employees' productivity as a result of these benefits } \\
\text {-Help companies to maintain their trained employees against their top competitors } \\
\text {-Create a win-win situation for company } \\
\text {-Provide an encouraging atmosphere for employees } \\
\text {-Provide supplementary training for its employees to meet the specific requirement }\end{array}$ \\
\hline Level Two & $\begin{array}{l}\text { Level two refers to the costs } \\
\text { which companies incur at the } \\
\text { higher levels to pay human } \\
\text { resource-related costs as well as } \\
\text { experiencing high levels of long- } \\
\text { term benefits. }\end{array}$ & $\begin{array}{l}\text {-Fully cover the additional education and professional trainings' costs for employees } \\
\text {-Define penalty and compulsory period for the employees who would like to leave } \\
\text { their jobs before their contract expire } \\
\text {-Organizing company-specific training courses } \\
\text {-Implement Enterprise planning }\end{array}$ \\
\hline Level Three & $\begin{array}{l}\text { Level three refers to the human } \\
\text { resource costs which companies } \\
\text { incur to develop the human } \\
\text { capital for gaining their restricted } \\
\text { long-term benefits. }\end{array}$ & $\begin{array}{l}\text {-Prefer to specialize limited amount of costs to their internal training system } \\
\text { - Employ their employees from other companies }\end{array}$ \\
\hline Level Four & $\begin{array}{l}\text { Level four occurs when the } \\
\text { company spends much money for } \\
\text { its human resource and gain } \\
\text { limited profit practically. }\end{array}$ & $\begin{array}{l}\text {-Restrict the education to the employees of the company } \\
\text {-Allocate a lot of money for training } \\
\text {-Reduce and influence the ethical behavior of employees }\end{array}$ \\
\hline
\end{tabular}

\section{Human Capital Depreciation}

Formula 1 was used to change the human resource-related costs into the capital or depreciate them and then examine their effect on the balance sheet.

\section{Formula 1:}

$$
\mathrm{HC}=\sum \mathrm{E}_{\mathrm{i}}
$$

In this mathematical formula, "E" refers to the human capital-related costs and " $\mathrm{i}$ " refers to the each cost which can be changed to the human capital. Formula 2 shows that a certain amount of costs is depreciated and then listed as an expense on the balance sheet in each period. In this formula, it is supposed that all the benefits gain in the same way during the specified period of time and follows the straight-line depreciation.

Formula 2:

$$
\mathrm{HC}_{\mathrm{a}}=\left(\sum \mathrm{E}_{\mathrm{i}}\right) / \mathrm{N}
$$

$\mathrm{HC}_{\mathrm{a}}=$ Depreciation expense of human capital

$\mathrm{N}=$ Number of years for gaining benefits 
Formula 3 shows the amount of human resource-related costs which is changed into the capital in the following years should be mention on the balance sheet. All resources which change into the capital will be removed after passing $\mathrm{N}$ years and they will no longer be seen on the new balance sheets.

Formula 3:

$$
\begin{aligned}
& \mathrm{HC}=\left(\sum \mathrm{E}_{\mathrm{i})}-\left(\mathrm{P} \times \mathrm{HC}_{\mathrm{a}}\right)\right. \\
& \mathrm{P}=\text { Number of years }
\end{aligned}
$$

\section{Conclusion}

This study was conducted to develop an analysis framework to link the human capital costs to the results of long-term interests or profits for providing a model for representing human capital on the balance sheet. It presented a framework which is fruitful for management accounting and financial accounting as well. This paper classified human resource-related costs into four categories and then offered the common behavior for each target category to the companies. These companies were able to apply this framework for surveying human resource-related costs and then took appropriate management and accounting decisions. The payments which have long-term value could be reported on the balance sheet. In addition, this paper tried to study the company's most important asset which is the human capital from different dimensions. Then, the difference between human capital and other assets used by the organizations were explained accurately and finally a variety of models were offered to measure strategic resource accurately in the organizations. This study proposed the way to transform human resource-related costs into the human capital and identified a common approach which is used as intangible assets by all companies on the balance sheet. This paper helps to improve the expressed financial statements regarding the human capital. It is also useful for financial experts and accountants as well as other potential users of financial reports.

\section{References}

Andreou, A. N., Green, A., \& Stankosky, M. (2007). A framework of intangible valuation areas and antecedents. Journal of Intellectual Capital, 8(1), 52-75.

Barney, J. B. (1991). Firm resources and sustainable competitive advantage. Journal of Management, 17(1), 99-120.

Beaver, W. H. (1998). Financial reporting: An accounting revolution. Upper Saddle River, NJ: Prentice-Hall.

Bontis, N., Dragonetti, N. C., Jacobsen, K., \& Roos, G. (1999). The knowledge toolbox: A review of the tools available to measure and manage intangible resources. European Management Journal, 17(4), 391-402.

Bose, R. (2004). Knowledge management metrics. Industrial Management \& Data Systems, 104(6), 457-468.

Brooking, A. (1996). Intellectual capital: Core assets for third millennium enterprise. London: International Thompson business press.

Brummet, R. L., Flamholtz, E., \& Pyle, W. C. (1968a). Accounting for human resources. Michigan Business Review, 20(2), $20-25$.

Brummet, R. L., Flamholtz, E., \& Pyle, W. C. (1968b). Human resource measurement: A challenge for accountants. The Accounting Review, 43(2), 217-224.

Chang, S. L. (2007). Valuing intellectual capital and firms' performance: Modifying value added intellectual coefficient (VAICTM) in Taiwan IT industry (Doctoral dissertation). Golden Gate University, United States, California.

Chen, M. C., Cheng, S. J., \& Hwang, Y. (2005). An empirical investigation of the relationship between intellectual capital and firms' market value and financial performance. Journal of Intellectual Capital, 6(2), 159-176.

Choong, K. K. (2008). Intellectual capital: Definitions, categorization, and reporting models. Journal of Intellectual Capital, $9(4), 609-638$. 
Edvinsson, L. (1998). El capital intellectual. México: Norma.

Edvinsson, L., \& Malone, M. (1997). Intellectual capital: Realizing your company’s true value by finding its hidden brain power. New York: Harper Business.

Elias, N. S. (1972). The effects of human asset statements on the investment decision: An empirical research in accounting. Selected Studies, 1,215-233.

Hall, R. (1992). The strategic analysis of intangible resources. Strategic Management Journal, 13(2), 135-144.

Kaplan, R., \& Norton, D. (1992). The balanced scorecard: Measures that drive performance. Harvard Business Review, 70(1), 71-79.

Levy, F. (2009). A simulated approach to valuing knowledge capital (Doctoral dissertation). The George Washington University, United States, Columbia.

Ohlson, J. A. (1995). Earnings, book values, and dividends in equity valuation. Contemporary Accounting Research, 11(2), 661-687.

Oliver, J., \& Flamholtz, E. (1978). Human resource replacement cost numbers, cognitive information processing and personnel decisions: A laboratory experiment. Journal of Business Finance \& Accounting, 5(2), 137-157.

Peteraf, M. A. (1993). The cornerstones of competitive advantage: A resource based view. Strategic Management Journal, 14(3), 179-191.

Pulic, A. (2004). Intellectual capital: Does it create or destroy value? Measuring Business Excellence, 8(1), 62-68.

Reed, K. K., Lubatkin, M., \& Srinivasan, N. (2006). Proposing and testing an intellectual capital- based view of the firm. Journal of Management Studies, 43(4), 867-893.

Rodov, I., \& Leliaert, P. (2002). FiMIAM: Financial method of intangible assets measurement. Journal of Intellectual Capital, 3(3), 323-336.

Roos, G., Pike, S., \& Fernström, L. (2005). Managing intellectual capital in practice. Amsterdam, The Netherlands: Elsevier.

Roos, G., \& Roos, J. (1997). Measuring your company's intellectual performance. Long Range Planning, 30(3), 325-326.

Roos, G., Roos, J., Edvinsson, L., \& Dragonetti, N. C. (1997). Intellectual capital: Navigating in the new business landscape. London: Macmillan Press.

Rylander, A., Jacobsen, K., \& Roos, G. (2000). Towards improved information disclosure on intellectual capital. International Journal of Technology Management, 20, 715-741.

Samudhram, A., Sivalingam, G., \& Shanmugam, B. (2010). Non-disclosure of human capital-based information: Theoretical perspectives. Journal of Human Resource Costing \& Accounting, 14(2), 106-128.

Schultz, T. P. (1981). Economics of populations. Reading, MA: Addison-Wesley.

Schwan, E. S. (1976). The effects of human resource accounting data on financial decisions: An empirical test. Accounting, Organizations \& Society, 1(2/3), 219-237.

Stewart T. A. (1997). Intellectual capital: The new wealth of organizations. New York, NY: Doubleday.

Sveiby, K. E. (1997). The new organizational wealth: Managing and measuring knowledge- based assets. San Francisco, CA: Barrett-Kohler.

Tobin, J. (1969). A general equilibrium approach to monetary theory. Journal of Money, Credit, \& Banking, 1(1), 15-29.

Zeghal, D., \& Maaloul, A. (2010). Analyzing value added as an indicator of intellectual capital and its consequences on company performance. Journal of Intellectual Capital, 11(1), 39-60. 